\title{
Replacing Added Nitrite by Kitaibelia Vitifolia Extract in Dry Fermented Sremska Sausage
}

\author{
Vladimir S. Kurćubic ${ }^{1 *}$, Pavle Z. Mašković ${ }^{2}$, Slavica M. Vesković ${ }^{3}$, \\ Jelena M. Mašković ${ }^{2}$
}

${ }^{1}$ University of Kragujevac, Faculty of Agronomy, Department of Food

Technology,

Cara Dušana 34, 32000 Čačak, Republic of Serbia

${ }^{2}$ University of Kragujevac, Faculty of Agronomy, Department of Chemistry and Chemical Engineering, Cara Dušana 34, 32000 Čačak, Republic of Serbia

${ }^{3}$ Institute for Meat Hygiene and Technology, Kaćanskog 13, 11000 Belgrade, Republic of Serbia

Corresponding author: vkurcubic@kg.ac.rs

\begin{abstract}
The effect of replacement of nitrite by the ethanol extract of Kitaibelia vitifolia on the microbiological safety and oxidative stability of dry fermented Sremska sausages (SS) was investigated. Spices and nitrite salt were added to the control group - batch (B I). Modified nitrite-free formulations of SS were produced with the addition of two different amounts of plant extracts $(360 \mathrm{~mL}$ per $20 \mathrm{~kg}$ of fillings in B II and $600 \mathrm{~mL}$ per $20 \mathrm{~kg}$ of fillings in B III). The larger addition of the herb extract revealed strong antimicrobial activity, when Minimum Inhibitory Concentrations were determined for 8 microbial strains by microdilution method. The results revealed the highest susceptibility of Escherichia coli and Proteus mirabilis. DPPH (2,2-diphenyl-1-picrylhydrazyl) free radical scavenging activity showed the strongest antioxidant activity in non-vacuumed and vacuumed SS samples obtained from B III, enriched with the larger amount of the herb extract.
\end{abstract}


Keywords: Kitaibelia vitifolia, antimicrobial activity, antioxidant activity, dry fermented Sremska sausage.

\section{Introduction}

Quality, food safety, nutrition and health are interrelated. For a large part of population, recent and important changes have reduced nutritional needs without affecting our sensorial needs (Vandendriessche, 2008).

Sremska sausage is a fermented sausage now produced under industrial conditions by slow fermentation and ripening to simulate the traditional production process. Households traditionally produce Sremska sausages in the cold period of the year. The sausages are generally made from the meat of pigs slaughtered the same day.

Microbial contamination may lead to public health hazards and economic loss caused by food poisoning and meat spoilage. Many secondary herb metabolites have antimicrobial activities that make them useful in the prevention or treatment of bacterial, viral and fungal infections (Alzoreky and Nakahara, 2003; Iqbal et al., 2005). Natural products showing in vitro antimicrobial effects have limited application, but these data serve as a starting point for investigations of these herbs and extracts in food. The protective role of flavonoids against microbial invasion is well known (Cushnie and Lamb, 2005).

Various herb extracts primarily contain phenolic compounds, which are potent antioxidants (Maskovic et al., 2011a; Mašković et al., 2011b; Mašković et al., 2012). Phenolic compounds occur only in herbal material and may protect food components from oxidation. Some phenolic compounds of plant extracts (sage, rosemary, thyme, hops, coriander, tea, cloves and basil extracts), including rosmarinic acid, are known to possess antimicrobial effects against foodborne pathogens (Davidson and Naidu, 2000; Elgayyar et al., 2001).

The design of our investigation was supported by the results obtained by the examination of the ethanol extract of the aboveground part of the Serbian herb Kitaibelia vitifolia by high-performance liquid chromatography coupled with diode-array detection (HPLC/DAD) analysis, which showed rosmarinic acid as the dominant compound (Maskovic et al., 2011a). A lower content was determined for p-hydroxybenzoic acid and caffeic acid. The above mentioned results suggest that the active principles of $K$. vitifolia have the potential to be used in preservation of meat products. Dry fermented sausages can constitute functional food (Mendoza et al., 2001; Muguerza et al., 2004).

Lipid oxidation in foods of animal origin leads to reduction of their nutritional value and undesirable flavor and color changes, and may be prevented using synthetic or natural antioxidants (Aguirrezábal et al., 2000; Leroy et al., 2006). Many additives are harmful for human health (monosodium glutamate, aspartame, saccharin, sodium cyclamate, sulfites, nitrates, nitrites and antibiotics) and cause headache, nausea, weakness, mental retardation, seizures, cancer and 
anorexia (Rangan and Barceloux, 2009). According to the safety and toxicity testing demands, replacement of synthetic preservatives, antioxidants or other food additives have focused research into functional properties of herb extracts (Dorman and Hiltunen, 2004; Al-Bakri and Afifi, 2007; Shahidi, 2008; Singh et al., 2010; Keskin and Toroglu, 2011), which may be useful for maintaining meat quality, extending shelf-life and preventing economic loss (Yin and Cheng, 2003; Badi et al., 2004).

The aim of this work was to develop dry fermented Sremska sausages (SS) without nitrite salts, using a suitable amount of the ethanol extract of the aboveground parts of $K$. vitifolia as a useful antimicrobial and antioxidant agent on the basis of its biological activity.

\section{Materials and methods}

\section{Plant material}

$K$. vitifolia is an impressive and undemanding Mallow from exYugoslavia. Above-ground parts of the test plant were collected in Central Serbia, in May 2009, at the flowering stage. Taxonomic identities of this herb were authenticated by Dr. Dmitar Lakušić at the Department of Botany, Faculty of Biology, University of Belgrade, Serbia (voucher specimen 16350 BEOU).

\section{Preparation of plant extract}

Plant samples $(10.0 \mathrm{~g})$ were extracted by $96 \%$ ethanol or ethanol $(100.0$ $\mathrm{mL})$ as a solvent. The extraction process was carried out using a B-220 ultrasonic bath (Branson and Smith-Kline, Danbury, Connecticut, USA) at room temperature for 1 hour. After filtration, $5 \mathrm{~mL}$ of the liquid extract was used for extraction yield determination. The solvent was removed by a rotary evaporator (Devarot, Elektromedicina, Ljubljana, Slovenia) under vacuum, and was dried at $60{ }^{\circ} \mathrm{C}$ to constant weight. The dried extracts were stored in glass bottles at $4{ }^{\circ} \mathrm{C}$ to prevent oxidative damage until analysis.

\section{Sausage formulation and processing}

Three batches (B) of dry fermented Sremska sausages (SS), about $20 \mathrm{~kg}$ each, were produced from a mixture of $50 \%$ frozen pork shoulder, $30 \%$ fresh pork meat cut-offs with $25 \%$ fat and $20 \%$ frozen pork back fat. Spices and additives (sweet pepper $0.5 \%$, hot red pepper $0.5 \%$, garlic $0.3 \%$, nitrite salt $2.5 \%$, and dextrose monohydrate $0.35 \%$ ) were added to B I. This original mixture recipe was used as the control sample. To assess the influence of various quantities of the herb extract, nitrites were replaced in the batch by $0.3 \% \mathrm{~K}$. vitifolia extract. Extract additions were $360 \mathrm{~mL}$ per $20 \mathrm{~kg}$ of fillings in B II and $600 \mathrm{~mL}$ per $20 \mathrm{~kg}$ 
of fillings in B III. All variants were produced on the same day and in an identical manner. Meat and fat were ground and minced in a meat grinder to about $8 \mathrm{~mm}$. During the mixing in a cutter, additives and spices were added. The mixture was stuffed in natural pork casing (small intestines) of around $36-38 \mathrm{~mm}$ diameter and hand-paired and were left to drain for $24 \mathrm{~h}$ at $22^{\circ} \mathrm{C}$. After 24 hours, the sausages were transported into an air-conditioned ripening chamber.

Drying and ripening were performed under controlled temperature and relative humidity conditions in an industrial chamber: $22{ }^{\circ} \mathrm{C} / 92 \%$ on 1 st day, 20 ${ }^{\circ} \mathrm{C} / 88 \%$ on 2 nd day, $19{ }^{\circ} \mathrm{C} / 86 \%$ on 3 rd day, $18{ }^{\circ} \mathrm{C} / 82 \%$ on 4 th day, $17{ }^{\circ} \mathrm{C} / 78 \%$ on 5th day and $15{ }^{\circ} \mathrm{C} / 72 \%$ from the 6th to 26th days. Sausages were smoked 5 hours daily (from the 3 rd to the 5 th $\mathrm{d}$ ) with beech wood filtrated smoke.

At the end of the ripening process, which lasted 26 days, each B of sausages was divided in two groups: one group of products was aerobically packed and the other group was vacuum (to 100\%) packed and labeled (VC 999, Inauen Machinen, Herisau, Switzerland, max. pressure $100 \mathrm{~Pa}$ ) using bags of polyethylene (PE) thickness $0.07 \mathrm{~mm}$ (Blik-produkt, Kikinda, Serbia). Analysis was carried out during storage at $4{ }^{\circ} \mathrm{C}$ after 44 day.

\section{Preparation of the aqueous sausage extract}

The extract of SS was prepared for testing of antioxidant and antimicrobial properties. Wrappers were removed from sausage samples, stuffed, chopped, and then homogenized in the blender. Ten grams of homogenized SS sample was taken and dissolved in $10 \mathrm{~mL}$ of distilled water to obtain a concentration of $1 \mathrm{mg}$ per $1 \mathrm{~mL}$ of distilled water.

\section{Determination of total phenolic content}

Total phenols were estimated according to the method used by a group of authors (Singleton et al., 1999). The prepared watery extract of sausages from control and experimental groups was diluted to the concentration of $1 \mathrm{mg} \cdot \mathrm{mL}^{-1}$, and aliquots of $0.5 \mathrm{~mL}$ were mixed with $2.5 \mathrm{~mL}$ of Folin-Ciocalteu reagent (previously diluted 10 -fold with distilled water) and $2 \mathrm{~mL}$ of $\mathrm{NaHCO}_{3}(7.5 \%)$. After $15 \mathrm{~min}$ at $45{ }^{\circ} \mathrm{C}$, the absorbance was measured at $765 \mathrm{~nm}$ using a spectrophotometer against a blank sample. Total phenols were determined as gallic acid equivalents (GAE) (expressed in grams of GAE per kilogram of extract), and the values are presented as means of triplicate analyses.

\section{Determination of flavonoid content}

Total flavonoids were determined according to the method used by a group of authors (Brighente et al., 2007). A total of $0.5 \mathrm{~mL}$ of $2 \%$ aluminum chloride $\left(\mathrm{AlCl}_{3}\right)$ in methanol was mixed with the same volume of watery extract of 
sausages from control and experimental groups. After 1 hour of staying at room temperature, the absorbance was measured at $415 \mathrm{~nm}$ in a spectrophotometer against the blank sample. Total flavonoids were determined as rutin equivalents (RU) (expressed in grams of RU per kilogram of dry extract), and the values are presented as means of triplicate analyses.

\section{Determination of total antioxidant capacity}

The total antioxidant activity of $K$. vitifolia in the watery extract of experimental sausages was evaluated by the phosphomolybdenum method (Prieto et al., 1999). The assay is based on the reduction of Mo (VI) - Mo (V) by antioxidant compounds and subsequent formation of a green phosphate/Mo (V) complex at acid $\mathrm{pH}$. A total of $0.3 \mathrm{~mL}$ of sausage sample extract was combined with $3 \mathrm{~mL}$ of reagent solution $\left(0.6 \mathrm{~mol} \cdot \mathrm{L}^{-1}\right.$ sulfuric acid, $28 \mathrm{mmol} \cdot \mathrm{L}^{-1}$ sodium phosphate and $4 \mathrm{mmol} \cdot \mathrm{L}^{-1}$ ammonium molybdate). The tubes containing the reaction solution were incubated at $95{ }^{\circ} \mathrm{C}$ for $90 \mathrm{~min}$. Then, the absorbance of the solution was measured at $695 \mathrm{~nm}$ using spectrophotometer against the blank after cooling to room temperature. Methanol $(0.3 \mathrm{~mL})$ in place of sausage extract was used as the blank. Ascorbic acid (AA) was used as the standard and total antioxidant capacity was expressed as milligrams of ascorbic acid per kilogram of dry sausage extract.

\section{Determination of DPPH free radical scavenging activity}

The method used by a group of authors (Takao et al., 1994) was adopted with suitable modifications (Kumarasamy et al., 2007). DPPH (2,2-diphenyl-1picrylhydrazyl $)(8 \mathrm{mg})$ was dissolved in methanol $(100 \mathrm{~mL})$ to obtain a concentration of $80 \mu \mathrm{g} \cdot \mathrm{mL}^{-1}$. Serial dilutions were carried out with the stock solution $\left(1 \mathrm{mg} \cdot \mathrm{mL}^{-1}\right)$ of the watery extract of experimental sausage. Solutions (2 $\mathrm{mL}$ each) were then mixed with DPPH $(2 \mathrm{~mL})$ and allowed to stand for $30 \mathrm{~min}$ for any reaction to occur, and the absorbance was measured at $517 \mathrm{~nm}$. Ascorbic acid (AA), gallic acid (GA) and butylated hydroxytoluene (BHT) were used as reference standards and dissolved in methanol to make the stock solution with the same concentration $\left(1 \mathrm{mg} \cdot \mathrm{mL}^{-1}\right)$.

The control sample was prepared containing the same volume without test compounds or reference antioxidants. Ninety-five percent methanol sausage extract was used as a blank. The DPPH free radical scavenging activity was calculated using the following equation (1) and expressed as percentage inhibition values $(I)$.

$$
I=\frac{A_{c}-A_{S}}{A_{S}} \times 100
$$


Percentage inhibition values were calculated from the absorbance of the control (Ac) and of the sample (As), with the controls containing all reaction reagents except the extract or positive control substance.

The $\mathrm{IC}_{50}$ value, defined as the concentration of the test material that leads to $50 \%$ reduction in the free radical concentration, was calculated as micrograms per milliliter through a sigmoidal dose-response curve.

\section{Antimicrobial activity}

The antimicrobial activity of the watery extract of experimental sausage in vitro was analyzed against the following bacteria: Staphylococcus aureus ATCC 25923, Klebsiella pneumoniae ATCC 13883, Escherichia coli ATCC 25922, Proteus vulgaris ATCC 13315, Proteus mirabilis ATCC 14153, Bacillus subtilis ATCC 6633, and fungi: Candida albicans ATCC 10231 and Aspergillus niger ATCC 16404.

Minimal inhibitory concentrations (MIC) of the sausage extract and against the test bacteria were determined using the micro dilution method in 96 multiwell micro titer plates (Satyajit et al., 2007). All tests were performed in MullerHinton broth (MHB, Sigma-Aldrich, Saint Louis, Missouri, USA) with the exception of yeast, in which case Sabouraud dextrose broth (Sigma-Aldrich) was used. A total of $100 \mu \mathrm{L}$ stock solution of sausage extract (in ethanol, $200 \mu \mathrm{L} \cdot \mathrm{mL}^{-}$ $\left.{ }^{1}\right)$ was pipetted into the first row of the plate. Fifty $\mu \mathrm{L}$ of Mueller-Hinton or Sabouraud dextrose broth (supplemented with Tween 80, Sigma-Aldrich at a final concentration of $0.5 \%(\mathrm{v} / \mathrm{v})$ for analysis of sausage extract) was added to the other wells. Fifty microliters from the first test wells was pipetted into the second well of each microtiter line, and then $50 \mu \mathrm{L}$ of scalar dilution was transferred from the second to the twelfth well. Ten microliters of resazurin indicator solution (prepared by dissolution of a $270-\mathrm{mg}$ tablet in $40 \mathrm{~mL}$ of sterile distilled water) and $30 \mu \mathrm{L}$ of nutrient broth were added to each well. Ten microliters of bacterial suspension $\left(106 \mathrm{CFU} \cdot \mathrm{mL}^{-1}\right)$ and yeast spore suspension $(3 \times 104$ $\mathrm{CFU} \cdot \mathrm{mL}^{-1}$ ) was added to each well. For each strain, the growth conditions and the sterility of the medium were checked. Standard antibiotic amracin was used as a control to check the sensitivity of the tested bacteria, whereas ketoconazole was used as control against the tested yeast. Plates were covered loosely with a cling film in order to ensure that the bacteria would not become dehydrated. The plates were afterwards placed into an incubator at $37^{\circ} \mathrm{C}$ for $24 \mathrm{~h}$ for the bacteria and at $28^{\circ} \mathrm{C}$ for $48 \mathrm{~h}$ for the yeast. Color change was then assessed visually. Any color change from purple to pink or colorless was recorded as positive. The lowest concentration at which color change occurred was taken as the MIC value. The average of 3 values was calculated and represented the MIC for the tested compounds and standard drug. 


\section{Statistical analysis}

The results of antioxidant activity examinations were presented as mean \pm standard deviations of three determinations. All computations were made by employing the statistical software SPSS, version 15.0 (SPSS, Inc, Chicago, IL, USA). $\mathrm{IC}_{50}$ values were calculated by nonlinear regression analysis from the sigmoidal dose-response inhibition curve.

\section{Results and Discussion}

The results on the antimicrobial activity of the examined extract in untreated and modified sausages obtained by the dilution method are given in Table 1 . The results reveal antimicrobial activity within the concentration range from 15.6$250.0 \mu \mathrm{g} \cdot \mathrm{mL}^{-1}$. The highest susceptibility among the bacteria tested was exhibited by Escherichia coli ATCC 25922 (B II and B III) and Proteus mirabilis ATCC 14153 (B II), followed by Staphylococcus aureus ATCC 25923 and Klebsiella pneumoniae ATCC 13883 (B II and B III), Proteus vulgaris ATCC 13315 (B II and B III), and Proteus mirabilis ATCC 14153 (B III). The lowest susceptibility among the tested bacteria was exhibited by Bacillus subtilis ATCC 6633, in B II and III samples. Among the fungi, Aspergillus niger ATCC 16404 in B II and in B III showed the highest susceptibility, and Candida albicans ATCC 10231 in B II and B III the lowest.

The comparison of the results on antimicrobial activity between untreated controls (nitrite, but without plant extract) and treated group (without nitrite, but with two different quantities of plant extracts) showed a small effect (only one dilution more) on Klebsiella pneumoniae, Staphylococcus aureus, Escherichia coli, which did not increase with increasing quantities of the herb extract.

Antimicrobial activities were compared with those of standard antibiotic amracin and ketoconazole (standard antimycotic). The results revealed that amracin and ketoconazole had mainly stronger antibacterial and/or antifungal effects than the herb extract or nitrite salt tested, as shown in Table 1. The various extract amounts in SS samples show influence on activities against Escherichia coli, but both amounts have stronger inhibitory effects on the tested bacteria than amracin $\left(15.6 \mu \mathrm{g} \cdot \mathrm{mL}^{-1}\right.$ vs. $\left.31.2 \mu \mathrm{g} \cdot \mathrm{mL}^{-1}\right)$. In a study by Nanasombat and Lohasupthawee (2005), Escherichia coli were resistant to most of the nine examined ethanol extracts, but the present ethanol extracts of $K$. vitifolia have significantly higher levels of antibacterial activity against Escherichia coli and Klebsiella pneumoniae in relation to all of these extracts. 
Table 1. Minimum Inhibitory Concentrations (MIC) of the watery extracts of dry fermented Sremska sausages

\begin{tabular}{|c|c|c|c|c|c|c|}
\hline \multicolumn{7}{|c|}{$\boldsymbol{M I C}\left(\mu \mathrm{g} \cdot \mathrm{mL}^{-1}\right)$} \\
\hline Microbial strains & $\begin{array}{c}\text { ATCC } \\
\text { number }\end{array}$ & $B I$ & B II & B III & Amracin & Ketoconazole \\
\hline \multicolumn{7}{|c|}{ Bacteria } \\
\hline $\begin{array}{l}\text { Staphylococcus } \\
\text { aureus }\end{array}$ & 25923 & 62.5 & 31.2 & 31.2 & 0.9 & / \\
\hline $\begin{array}{l}\text { Klebsiella } \\
\text { pneumoniae }\end{array}$ & 13883 & 62.5 & 31.2 & 31.2 & 0.4 & l \\
\hline Escherichia coli & 25922 & 31.2 & 15.6 & 15.6 & 31.2 & / \\
\hline Proteus vulgaris & 13315 & 31.2 & 31.2 & 31.2 & 0.4 & / \\
\hline Proteus mirabilis & 14153 & 15.6 & 15.6 & 31.2 & 0.4 & / \\
\hline Bacillus subtilis & 6633 & 125.0 & 125.0 & 125.0 & 0.2 & I \\
\hline \multicolumn{7}{|c|}{ Fungi } \\
\hline Candida albicans & 10231 & 250.0 & 250.0 & 250.0 & 1 & 1.9 \\
\hline Aspergillus niger & 16404 & 125.0 & 62.5 & 125.0 & l & 0.9 \\
\hline
\end{tabular}

The results on total phenols, flavonoids and total antioxidant capacity are presented in Table 2. Total phenols and flavonoids were highest in nonvacuumed and vacuumed sausages from B III. This result revealed that the ethanol extract of the herb, $K$. vitifolia, exhibits a stronger antioxidant activity in the larger amount (360 mL per $20 \mathrm{~kg}$ of fillings vs. $600 \mathrm{~mL}$ per $20 \mathrm{~kg}$ of fillings), with the highest total antioxidant capacity for non-vacuumed and vacuumed SS samples from B III. Other samples showed significantly lower activity, which is consistent with the results of total phenolic compounds.

Table 2. Total phenol and flavonoid content and total antioxidant capacity of the watery extracts of dry fermented Sremska sausages tested during storage at 4 ${ }^{\circ} \mathrm{C}$ after 44 days

\begin{tabular}{lccc}
\hline Packaging/B number & $\begin{array}{c}\text { Total } \\
\text { Pholics } \\
\left(\mathrm{g} \cdot \mathrm{kg}^{-1}\right)\end{array}$ & $\begin{array}{c}\text { Flavonoids } \\
\left(\mathrm{g} \cdot \mathrm{kg}^{-1}\right)\end{array}$ & $\begin{array}{c}\text { Total Antioxidant } \\
\text { Capacity } \\
\left(\mathrm{mg} \cdot \mathrm{kg}^{-1}\right)\end{array}$ \\
\hline Non-vacuumed B I & $60.3 \pm 0.7$ & $29.2 \pm 0.5$ & $59.4 \pm 0.9$ \\
Non-vacuumed B II & $63.6 \pm 0.9$ & $26.8 \pm 0.3$ & $55.1 \pm 0.4$ \\
Non-vacuumed B III & $76.4 \pm 0.8$ & $34.7 \pm 0.3$ & $74.5 \pm 0.3$ \\
Vacuumed B I & $60.7 \pm 0.8$ & $34.2 \pm 0.9$ & $60.9 \pm 0.3$ \\
Vacuumed B II & $63.7 \pm 0.7$ & $27.8 \pm 1.0$ & $59.9 \pm 0.3$ \\
Vacuumed B III & $78.9 \pm 0.5$ & $35.4 \pm 0.9$ & $68.9 \pm 0.7$ \\
\hline
\end{tabular}


Total phenolics are expressed as grams of gallic acid equivalent per kilogram of extract. Flavonoids are expressed as grams of rutin equivalents per kilogram of dry extract. Total antioxidant capacity is expressed as milligrams of ascorbic acid per kilogram.

$\mathrm{IC}_{50}$ values were determined for each measurement (Table 3), and revealed the strongest antioxidant activity in sausage samples from non-vacuumed and vacuumed B III, in DPPH free radical scavenging activity.

Table 3. Antioxidant activity in the watery extract of dry fermented Sremska sausage and standards during storage at $4{ }^{\circ} \mathrm{C}$ after 44 days

\begin{tabular}{lc}
\hline & ${ }^{\mathrm{a}} \mathrm{IC}_{50}\left(\mu \mathrm{g} \cdot \mathrm{mL}^{-1}\right)$ \\
\hline Packaging/B number & $\begin{array}{c}\mathrm{DPPH} \\
\text { scavenging } \\
\text { activity }\end{array}$ \\
\hline Non-vacuumed B I & $42.8 \pm 0.9$ \\
Non-vacuumed B II & $36.4 \pm 0.8$ \\
Non-vacuumed B III & $23.7 \pm 0.8$ \\
Vacuumed B I & $29.7 \pm 0.7$ \\
Vacuumed B II & $28.9 \pm 0.5$ \\
Vacuumed B III & $22.6 \pm 0.9$ \\
Gallic acid & $3.8 \pm 0.7$ \\
Ascorbic acid & $6.1 \pm 0.3$ \\
BHT & $15.6 \pm 1.3$ \\
a-Tocopherol & - \\
\hline
\end{tabular}

Results are mean \pm SD values from three experiments.

The $50 \%$ inhibitory concentration $\left(\mathrm{IC}_{50}\right)$ values were determined by nonlinear regression analysis.

BHT, butylated hydroxytoluene; DPPH, 2,2-diphenyl-1-pycrilhydrazyl.

The manifested antioxidant effect of the tested extracts in SS was considered significant due to the fact that the fermented sausage obtained from frozen meat and fat tissue stored for a long time easily oxidizes, that lipolysis is more intense than in the swine and cattle meat, and that all flavonoids show antioxidant activity in hydrophilic environments, but this activity is reduced in lipophilic environments (Finotti and Di Majo, 2003). Packaging products in vacuum slows the oxidation of fat (Ansorena and Astiasaran, 2004).

Dry fermented Sremska sausages containing $0.3 \%$ extract in $600 \mathrm{~mL}$ per 20 $\mathrm{kg}$ of fillings appeared to have slower rates of oxidation than those with nitrite salts. The antioxidant capacity related to the DPPH radical revealed that the values of the SS supplemented with the examined extract were lower than those of the control sausages, indicating a stronger antioxidant activity in the treated B than in the control group (with nitrite salt, usually used as a preservative). The antioxidant capacity in the analyzed sausages is associated with the phenol and 
flavonoid content, which suggests that processing and storage conditions that would help to preserve these compounds in SS should be sought in order to make the product beneficial for consumers. Previous studies showed that rosmarinic acid has many biological activities: astringent, antioxidant, anti-inflammatory, anti-mutagenic, antibacterial and antiviral. It also can provide protection against cancer (Petersen and Simmonds, 2003).

Carlsen et al. (2010) screened various foods to identify total antioxidant capacity of fruits, vegetables, beverages, spices and herbs in a large number of samples and found that plant-based foods are generally higher in antioxidant content than animal-based and mixed food products, with median antioxidant values of $8.8 \mathrm{mmol} \cdot \mathrm{kg}^{-1}, 1.0 \mathrm{mmol} \cdot \mathrm{kg}^{-1}$ and $3.1 \mathrm{mmol} \cdot \mathrm{kg}^{-1}$, respectively. The mean value for medicinal herbs was $917.0 \mathrm{mmol} \cdot \mathrm{kg}^{-1}$. As regards antioxidant contents, clove has the highest mean antioxidant value among spices and herbs (products from six various manufacturers, with product label and country of origin data showed different levels: $1255.5 \mathrm{mmol} \cdot \mathrm{kg}^{-1}, 4653.2 \mathrm{mmol} \cdot \mathrm{kg}^{-1}$ in dried aboveground part of the plant and $1753.1 \mathrm{mmol} \cdot \mathrm{kg}^{-1}, 3179.6 \mathrm{mmol} \cdot \mathrm{kg}^{-1}, 3277.7$ $\mathrm{mmol} \cdot \mathrm{kg}^{-1}$ and $2520.4 \mathrm{mmol} \cdot \mathrm{kg}^{-1}$ in dried whole plant). These values are significantly lower compared to the results obtained in our study.

\section{Conclusion}

The present study confirmed the strong antimicrobial effectiveness and antioxidant activities of the ethanol extract of the Serbian plant $K$. vitifolia in preserving dry fermented Sremska sausage. The high contents of phenolic and flavonoid compounds revealed great antimicrobial and antioxidant effects in examined sausages. Therefore, the larger amount exhibiting stronger activities may be used in further development of dry fermented sausages to retard oxidative rancidity and microbial growth, providing safer products for consumers. The obvious advantages of using $K$. vitifolia ethanol extract to inhibit lipid oxidation during storage and the possible replacement of nitrites by the herb extract in dry fermented sausages and other meat products require further investigation.

\section{Acknowledgments}

This research was supported by the Ministry of Education, Science and Technological Development of the Republic of Serbia, Projects III 46009. 


\section{References}

Aguirrezábal M.M., Mateo J., Domínguez M.C., Zumalac-árregui J.M. (2000): The effect of paprika, garlic and salt on rancidity in dry sausages. Meat Science, 54: 77-81.

Al-Bakri G.A., Afifi U.F. (2007): Evaluation of antimicrobial activity of selected plant extracts by rapid XTT colorimetry and bacterial enumeration. Journal of Microbiological Methods, 68: 19-25.

Alzoreky N.S., Nakahara K. (2003): Antibacterial activity of extracts from some edible plants commonly consumed in Asia. International Journal of Food Microbiology, 80: 223-230.

Ansorena D., Astiasaran I. (2004): Effect of storage and packaging on fatty acid composition and oxidation in dry fermented sausages made with added olive oil and antioxidants. Meat Science, 67: 237-244.

Badi H.N., Yazdani D., Ali S.M., Nazari F. (2004): Effects of spacing and harvesting time on herbage yield and quality/quantity of oil in thyme, Thymus vulgaris L.. Industrial Crops and Products, 19: 231-236.

Brighente I.M.C., Dias M., Verdi L.G., Pizzolatti M.G. (2007): Antioxidant activity and total phenolic content of some Brazilian species. Pharmaceutical biology, 45: 155161.

Carlsen M.H., Halvorsen B.L., Holte K., Bøhn S.K., Dragland S., Sampson L., Willey C., Senoo H., Umezono Y., Sanada C., Barikmo I., Berhe N., Willett W.C., Phillips K.M., Jacobs D.R., Blomhoff R. (2010): The total antioxidant content of more than 3100 foods, beverages, spices, herbs and supplements used worldwide. Nutrition Journal: 9:3.

Cushnie T.P., Lamb A.J. (2005): Antimicrobial activity of flavonoids. International Journal of Antimicrobial Agents: 26, 343-356.

Davidson P.M., Naidu A.S. (2000): Phyto-phenols. In: Naidu, A.S. (ed.), Natural food antimicrobial system, CRC Press, Boca Raton, U.S.A.: 265-294.

Dorman H.J.D., Hiltunen R. (2004): Fe (III) reductive and free radical-scavenging properties of summer savory (Satureja hortensis L.) extract and subfractions. Food Chemistry, 88: 193-199.

Elgayyar M., Draughon F.A., Golden D.A., Mount J.R. (2001): Antimicrobial activity of essential oils from plants against selected pathogenic and saprophytic microorganisms. Journal of Food Protection, 64: 1019-1024.

Finotti E., Di Majo D. (2003): Influence of solvents on the antioxidant property of flavonoids. Nahrung, 47: 186-187.

Iqbal K., Nawaz S.A., Malik A., Riaz N., Mukhtar N., Mohammad P., Choudhary M.I. (2005): Isolation and lipoxygenase-inhibition studies of phenolic constituents from Ehretia obtusifolia. Chemistry \& Biodiversity, 2: 104-111.

Keskin D., Toroglu S. (2011): Studies on antimicrobial activities of solvent extracts of different spices. Journal of Environmental Biology, 32: 251-256.

Kumarasamy Y., Byres M., Cox P.J., Jaspars M., Nahar L., Sarker S.D. (2007): Screening seeds of some Scottish plants for free-radical scavenging activity. Phytotherapy research, 21: 615-621.

Leroy F., Verluyten J., De Vuyst L. (2006): Functional meat starter cultures for improved sausage fermentation. International Journal of Food Microbiology, 106: 270-285. 
Mašković P., Dragišić-Maksimović J., Maksimović V., Blagojević J., Vujošević M., Manojlović N.T., Radojković M., Cvijović M., Solujić S. (2012): Biological activities of phenolic compounds and ethanolic extract of Halacsya sendtneri (Boiss.) Dörfler. Central European Journal of Biology, 7: 327-333.

Maskovic P., Solujic S., Mihailovic V., Mladenovic M., Cvijovic M., Mladenovic J., Acamovic-Djokovic G., Kurcubic V. (2011a): Phenolic Compounds and Biological Activity of Kitaibelia vitifolia. Journal of Medicinal Food, 14: 1617-1623.

Mašković P.Z., Mladenović J.D., Cvijović M.S., Aćamović-Đoković G., Solujić S.R., Radojković M.M. (2011b): Phenolic content, antioxidant and antifungal activities of acetonic, ethanolic and petroleum ether extracts of Hypericum perforatum L. Chemical Industry, 65: 159-164.

Mendoza E., Garcia M.L., Casa C., Slgas M.D. (2001): Inulin as fat substitute in low fat dry fermented sausages. Meat Science, 57: 387-393.

Muguerza E., Gimeno O., Ansorena D., Astiasaran I. (2004): New formulations for healthier dry fermented sausage: a review. Trends in Food Science \& Technology, 15: 452-457.

Nanasombat S., Lohasupthawee P. (2005): Antibacterial activity of crude ethanolic extracts and essential oils of spices against Salmonellae and other Enterobacteria. KMITL-STJ, 5: 527-538.

Petersen M., Simmonds M.S.J. (2003): Rosmarinic acid. Phytochemistry, 62: 121-125.

Prieto P., Pineda M., Aguilar M. (1999): Spectrophotometric quantitation of antioxidant capacity through the formation of a phosphomolybdenum complex: specific application to the determination of vitamin E. Analytical biochemistry, 269: 337-341.

Rangan C., Barceloux D.G. (2009): Food additives and sensitivities. Disease-a-Month, 55: 292-311.

Satyajit D., Sarker L.N., Kumarasamy Y. (2007): Microtitre plate based antibacterial assay incorporating resazurin as indicator of cell growth, and its application in the in vitro antibacterial screening of phytochemicals. Methods, 42: 321-324.

Shahidi F. (2008): Antioxidants: Extraction, identification, application and efficacy measurement. The Electronic Journal of Environmental, Agricultural and Food Chemistry, 7: 3255-3261.

Singh A., Sharma P.K., Garg G. (2010): Natural products as preservatives. International Journal of Pharma and Bio Sciences, 1, 601-612.

Singleton V., Orthofer R., Lamuela-Raventos R.M. (1999): Analysis of total phenols and other oxidation substrates and antioxidants by means of Folin-Ciocalteu reagent. Methods in enzymology, 299: 152-178.

Takao T., Watanabe N., Yagi I., Sakata K. (1994): A simple screening method for antioxidants and isolation of several antioxidants produced by marine bacteria from fish and shellfish. Bioscience, Biotechnology, and Biochemistry, 58: 1780-1783.

Vandendriessche F. (2008): Meat products in the past, today and in the future. Meat Science, 78: 104-113.

Yin M.C., Cheng W.S. (2003): Antioxidant and antimicrobial effects of four garlicderived organosulfur compounds in ground beef. Meat Science, 63: 23-28. 


\title{
ZAMENA DODATOG NITRITA EKSTRAKTOM KITAIBELIA VITIFOLIA U FERMENTISANOJ SUVOJ SREMSKOJ KOBASICI
}

\author{
Vladimir S. Kurćubić ${ }^{1}$, Pavle Z. Mašković ${ }^{2}$, Slavica M. Vesković ${ }^{3}$, Jelena M. \\ Mašković \\ ${ }^{1}$ Univerzitet u Kragujevcu, Agronomski fakultet, Katedra za prehrambenu \\ tehnologiju, \\ Cara Dušana 34, 32000 Čačak, Republika Srbija \\ ${ }^{2}$ Univerzitet u Kragujevcu, Agronomski fakultet, Katedra za hemiju i hemijsko \\ inženjerstvo, Cara Dušana 34, 32000 Čačak, Republika Srbija \\ ${ }^{3}$ Institut za higijenu i tehnologiju mesa, Kaćanskog 13, 11000 Beograd, \\ Republika Srbija
}

\begin{abstract}
Rezime
Ispitivan je uticaj zamene nitrita etanolnim ekstraktom biljke Kitaibelia vitifolia na mikrobiološku bezbednost i oksidativnu stabilnost fermentisane suve Sremske kobasice (SS). Začini i nitritna so dodavani su kontrolnoj grupi - proizvodna serija (B I). Modifikovane recepture SS bez nitrita proizvedene su sa dodatkom dve različite količine biljnog ekstrakta $(360 \mathrm{~mL}$ na $20 \mathrm{~kg}$ nadeva u B II i $600 \mathrm{~mL}$ na $20 \mathrm{~kg}$ nadeva u B III). Veće količine dodatog biljnog ekstrakta pokazuju snažnu antimikrobnu aktivnost, kada je metodom mikrodilucije određivana Minimalna inhibitorna koncentracija za 8 mikrobnih sojeva. Ovi rezultati otkrivaju visoku osetljivost bakterija Escherichia coli i Proteus mirabilis. DPPH (2, 2-diphenyl-1-picrylhydrazyl) aktivnost „hvatanja” slobodnih radikala otkriva najjaču antioksidativnu aktivnost u uzorcima SS proizvodne serije III (B III), bilo da je nevakuumirana ili vakuumirana, koja je obogaćena većim količinama dodatog biljnog ekstrakta.
\end{abstract}

Ključne reči: Kitaibelia vitifolia, antimikrobna aktivnost, antioksidativna aktivnost, fermentisana suva Sremska kobasica. 